\title{
HHV-8 Seroprevalence and Genotype Distribution in Africa, 1998-2017: A Systematic Review
}

\author{
Elizabeth M. Etta ${ }^{1}$, Doyinmola P. Alayande ${ }^{1}{ }^{(D)}$, Lufuno G. Mavhandu-Ramarumo ${ }^{1}$, \\ George Gachara $^{2}$ (1) and Pascal O. Bessong ${ }^{1, *}$ \\ 1 HIV/AIDS \& Global Health Research Programme, University of Venda, Thohoyandou 0950, South Africa; \\ queenettamashu@gmail.com (E.M.E.); doyin_alayande@yahoo.com (D.P.A.); \\ lufuno.mavhandu@univen.ac.za (L.G.M.-R.) \\ 2 Department of Medical Laboratory Sciences, Kenyatta University, Nairobi 34556-00100, Kenya; \\ ggachara@gmail.com \\ * Correspondence: bessong@univen.ac.za or pascal.bessong@gmail.com; Tel.: +27-15-962-8301
}

Received: 27 May 2018; Accepted: 2 August 2018; Published: 27 August 2018

\begin{abstract}
Human herpes virus type 8 (HHV-8) is the causative agent of Kaposi's sarcoma (KS). We systematically reviewed literature published between 1998 and 2017, according to the PRISMA guidelines, to understand the distribution of HHV-8 infection in Africa. More than two-thirds (64\%) of studies reported on seroprevalence and $29.3 \%$ on genotypes; $9.5 \%$ were on both seroprevalence and genotypes. About $45 \%$ of African countries had data on HHV-8 seroprevalence exclusively, and more than half $(53 \%)$ had data on either seroprevalence or genotypes. Almost half $(47 \%)$ of the countries had no data on HHV-8 infection. There was high heterogeneity in the types of tests and interpretation algorithms used in determining HHV-8 seropositivity across the different studies. Generally, seroprevalence ranged from $2.0 \%$ in a group of young children in Eritrea to $100 \%$ in a small group of individuals with KS in Central African Republic, and in a larger group of individuals with KS in Morocco. Approximately $16 \%$ of studies reported on children. Difference in seroprevalence across the African regions was not significant (95\% CI, $\chi^{2}=0.86 ; p=0.35$ ), although specifically a relatively significant level of infection was observed in HIV-infected children. About $38 \%$ of the countries had data on $\mathrm{K} 1$ genotypes. K1 genotypes A, A5, B, C, F and Z occurred at frequencies of $5.3 \%, 26.3 \%, 42.1 \%, 18.4 \%, 5.3 \%$ and $2.6 \%$, respectively. Twenty-three percent of the countries had data for K15 genotypes, and genotypes $\mathrm{P}, \mathrm{M}$ and $\mathrm{N}$ occurred at frequencies of $52.2 \%, 39.1 \%$, and $8.7 \%$, respectively. Data on HHV-8 inter-genotype recombinants in Africa are scanty. HHV-8 may be endemic in the entire Africa continent but there is need for a harmonized testing protocol for a better understanding of HHV-8 seropositivity. K1 genotypes A5 and B, and K15 genotypes P and M, from Africa, should be considered in vaccine design efforts.
\end{abstract}

Keywords: HHV-8; seroprevalence; genotypes; systematic review; Africa

\section{Introduction}

Human herpes virus type 8 (HHV-8) is the causative agent of four classes of Kaposi's sarcoma (KS) [1]: endemic, classic, iatrogenic and AIDS-associated KS; of these, endemic-KS and AIDS-KS are the most aggressive. AIDS-KS has been highlighted in young homosexual men [2], while classic-KS is common in elderly Mediterranean people and individuals of Eastern Europe [3]. Furthermore [4], reported on endemic-KS, also called African endemic-KS, as common in children and young adults in sub-Saharan Africa. Iatrogenic-KS has been observed in immunosuppressed patients who had undergone a solid organ transplant $[5,6]$. 
Globally, the epidemiologic pattern of HHV-8 is uneven, but follows that of KS, and countries at high risk of $\mathrm{KS}$ report high prevalence of HHV-8. In a healthy population, there is great variability in the seroprevalence of HHV-8, as opposed to groups at increased risk of developing KS. HHV-8 undergoes both latent and lytic phases in its life cycle, whereby the virus remains within the host at a dormant stage until other cofactors trigger it to start replicating, leading to the lytic phase [7-9]. The mode of transmission of HHV-8 can either be vertical or horizontal, including mother to child transmission and from members of family units [10-12].

HHV-8 infection is ubiquitous in African regions with increased incidences of endemic Kaposi's sarcoma in the general population and AIDS-associated Kaposi's sarcoma in the HIV/AIDS population $[13,14]$. An increase in the incidence of KS has been observed due to HIV infection in Africa. However, with the scale up and improved access to combination antiretroviral therapy, it is expected that the incidence of KS may be mitigated as has been observed in the developed world $[15,16]$. In contrast to observations in US, studies have showed that HHV-8 seroprevalence increases from childhood to adulthood in African regions [17-19]. Treatment for HHV-8 or KS includes combined chemotherapy, such as vincristine, bleomycin and doxorubicin, radiation therapy, surgery and biological therapy that will effectively dissolve lesions whether localized or widespread, compared to a single HAART drug [20-22].

HHV-8 is characterized by high genetic variability across the entire genome, with the highest level of genetic variation observed at the $5^{\prime}$ and $3^{\prime}$ ends of the genome. HHV-8 has been classified into genotypes A, A5, B, C, D, E, F and Z based on the hypervariable regions (VR1 and VR2) of the K1 gene; while genotypes $\mathrm{P}, \mathrm{M}$ and $\mathrm{N}$ are based on the $\mathrm{K} 15$ gene. Generally, these genotypes have been identified globally [4,23-31]. Genotypes B, Q, R and N are ORF26 genotypes, of which genotypes B and $\mathrm{N}$ overlap with genotypes based on $\mathrm{K} 1$ and $\mathrm{K} 15$ genes.

There are several ongoing vaccines and therapeutic development efforts against HHV-8 [32-34]. In this backdrop, it is important to understand the burden of HHV-8 in Africa where the infection appears to be relatively common. The current systematic review examined and analyzed data on the prevalence and molecular epidemiology of HHV-8 in all African countries from 1998-2017.

\section{Methodology}

\subsection{Inclusion Criteria for Study Analysis}

We conducted a systematic review of published full text articles on HHV-8 seroprevalence and genotypes from 53 African countries, according to the PRISMA guidelines, except for meta-analysis. Sudan and South Sudan were considered as one country. Cross-sectional, case report, retrospective, prospective and observational studies on HHV-8 seroprevalence and/or genotypes were included for analysis. Full texts in the French language were interpreted, analyzed and included in the analysis. However, there were no full text articles in other languages that met the inclusion criteria. African countries were assessed and categorized into Central, East, North, Southern and West Africa.

\subsection{Relevant Literature Searches}

MEDLINE, EMBASE, SCOPUS, WEB OF SCIENCE databases and conference proceedings, were searched for published data from 1998-2017. Using electronic search, reference lists were screened for relevant and additional data.

\subsection{MEDLINE Search Strategy Using PubMed}

The search terms used were: $((((($ prevalence* OR epidemiology* OR incidence OR seroprevalence* OR seroepidemiology* OR sero-epidemiology* OR seropositivity* OR sero-positivity*)) OR ((()ro-epidemiologic studies [MeSH Terms] OR prevalence [MeSH Terms] OR incidence [MeSH Terms] $))))$ AND (((((((herpesvirus 8, human [Term] ) OR “human herpesrvirus 8”) OR “HHV8") OR "HHV-8" OR “KSHV" OR “kaposi sarcoma associated herpesvirus") OR "kaposi's sarcoma associated 
herpes-virus") OR "kaposi sarcoma-associated herpesvirus") OR "kaposi's sarcoma-associated herpesvirus") OR "kaposi sar-coma herpesvirus") OR kaposi virus))))) NOT ((animals[mh] NOT humans[mh])). In addition, each search strategy was complemented with other search criteria as follows: reviews of HHV-8/KSHV OR HHV-8 review and epidemiology OR genetic characterization of HHV-8/KSHV, genetic OR characterization of KSHV and genotype distribution of HHV-8 K1/K15. All these search options were accompanied with an African country (name). This was repeatedly done for all 53 African countries.

\subsection{EMBASE Search Strategy Using Science Direct}

The search terms were: \#1.1 "human herpesvirus 8"/exp OR "human herpesvirus 8" OR "HHV-8" OR "HHV8" OR "KSHV” OR "kaposi sarcoma associated herpesvirus" / exp OR "kaposi sarcoma associated herpesvirus" OR "kaposi sarcoma-associated herpesvirus" / exp OR "kaposi sarcoma-associated herpesvirus" OR kaposi NEXT/3 herpesvirus OR kaposi NEXT/3 virus AND [embase]/lim \#1.2 "prevalence" / exp OR prevalence OR "seroprevalence" / exp OR seroprevalence OR "incidence" / exp OR incidence OR "seroepidemiology" / exp OR seroepidemiology AND [embase]/lim \#1.3 prevalen* OR inciden* OR epidemiolog* OR sero*epidemiolog* OR sero*prevalen* OR sero*positiv* AND [embase]/lim \#1.4 \#1.2 OR \#1.3 \#1.5 \#1.1 AND \#1.4 \#1.6 “animals" / exp NOT “humans" / exp \#1.7 \#1.5 NOT \#1.6.])). In addition, each search strategy was concluded with additional options as thus: reviews of HHV-8/KSHV OR HHV-8 review and epidemiology OR genetic characterization of HHV-8/KSHV, genetic OR characterization of KSHV and genotype distribution of HHV-8 K1/K15. All these search options were accompanied with an African country (name). This was repeatedly done for all 53 African countries.

\subsection{SCOPUS Search Strategy Using Elsevier}

Search strategies were as follows: seroprevalence OR seroepidemiology OR sero-epidemiology OR seropositivity OR seropositivity OR sero-epidemiologic studies OR prevalence OR incidence AND herpesvirus 8, human OR human herpesrvirus 8 OR hhv-8 OR hhv-8 OR kshv OR kaposi sarcoma associated herpesvirus OR kaposi's sarcoma associated herpes-virus OR kaposi sarcoma-associated herpesvirus OR kaposi's sarcoma-associated herpesvirus OR kaposi sarcoma herpesvirus/kaposi virus OR reviews of HHV-8/KSHV OR HHV-8 review and epidemiology OR genetic characterization of HHV-8/KSHV OR genetic characterization of KSHV and genotype distribution of HHV-8 K1/K15. All these search options were accompanied with an African country (name). This was repeatedly done for all 53 African countries.

\subsection{Web of Science Search Strategy Using Analytic Database}

Search strategies were as follows: seroprevalence OR seroepidemiology OR sero-epidemiology OR seropositivity OR sero-positivity OR seroepidemiologic studies OR prevalence OR incidence and herpesvirus 8, OR human herpesvirus 8 OR HHV-8 OR KSHV OR kaposi sarcoma associated herpesvirus OR kaposi's sarcoma associated herpesvirus OR kaposi associated herpes virus OR kaposi's sarcoma associated herpes virus OR kaposi sarcoma herpesvirus OR kaposi sarcoma virus, reviews on epidemiology of $\mathrm{HHV}-8 / \mathrm{KSHV}$, genetic characterization of HHV-8/KSHV genotype distribution of HHV-8 K1/K15. All these search options were accompanied with an African country (name). This was repeatedly done for all 53 African countries.

\subsection{Searching Other Sources}

Additional searches were for additional data and the focus was on African countries. We screened reference lists of relevant papers and searched the following conferences: Annual Meeting of the American Society of Clinical Oncology (ASCO) (http://www.asco.org/ASCOv2/Meetings); International Conference on Malignancies in AIDS and Other Acquired Immuno-deficiencies 
(http:/ / www.capconcorp.com/meeting/2013/14thICMAOI/index.asp); Conference on Retroviruses and Opportunistic Infections (CROI) (www.croi2017.org).

\subsection{Data Extraction}

Two reviewers downloaded relevant articles from the above search options and classified each article using an article grid. These classifications were based on: the study objectives, design, sampling size, results, discussion and conclusion. For all included studies, information was extracted on: author(s), study type, country of study, country of participants, study population, sample size, sample type, number of males, number of females, number of children, type of assay, seroprevalence, source of DNA, K1 genotypes and K15 genotypes. We used ' $X$ ' for parameters with no information. The various tests used for the determination of HHV-8 seropositivity were also considered. These tests were immunofluorescence (IFA) and enzyme immunoassay (EIA), immuno-peroxidase (IMP), western blots and antigen ELISA tests (latent ORF73 and lytic K8.1). In addition, relevant articles on the genetic characterization of HHV-8 for K1 and K15 genes were analyzed. Figure 1 shows a PRISMA flow chart on the selection of studies included for analysis.

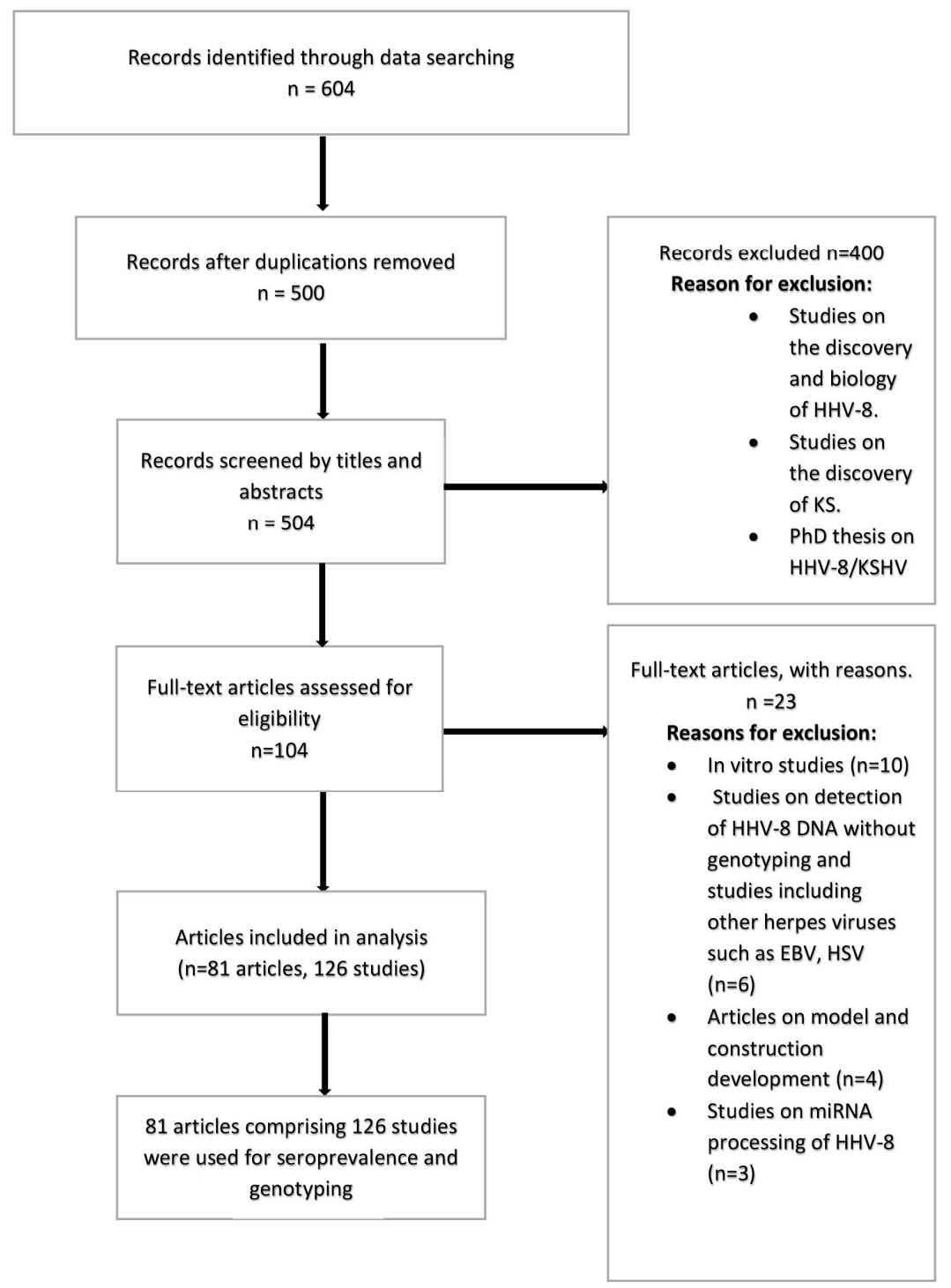

Figure 1. Flow chart on the selection of studies included for analysis. 


\section{Results}

The use of different approaches and algorithms to determine the sero-epidemiology of HHV-8 across different populations presents challenges for comparisons. Examples of these challenges include the use of different dilution factors in plasma or serum preparation for antibody detection, the use of ELISA with different principles and interpretation guidelines, different immunofluorescence techniques, or a combination of these approaches. In addition to these, the inclusion of different populations (low and high risk), even in the same study community, increases the degree of complexity in deciphering an accurate picture of the distribution of HHV-8 infection among populations. Consequently, herein, we firstly present a descriptive analysis of the systematic literature search on studies on HHV-8 sero-epidemiology in Africa. To extract salient sero-epidemiological features, amid the challenges posed by different methodologies, we performed, where plausible, comparable analysis for studies involving children, pregnant women, and for rural and urban populations, against the backdrop of the risk factors for HHV-8 acquisition, for the different regions of Africa (Southern, Central, West, East, and North Africa). Countries were categorized as follows: Southern Africa-Botswana, Zambia, Mozambique, South Africa, Zimbabwe, Namibia, Swaziland, Lesotho, Malawi; Central Africa-Angola, Cameroon, Central Africa Republic, Chad, Congo, Gabon, Democratic Republic of Congo, Equatorial Guinea, Sao Tome \& Principle; West Africa-Nigeria, Burkina Faso, Guinea, Gambia, Ghana, Mali, Senegal, Sierra Leonne, Niger, Liberia, Benin, Cote d'Ivoire, Togo, Cape Verde, Mauritania; East Africa-Tanzania, Kenya, Uganda, Ethiopia, Rwanda, Burundi, Djibouti, Eritrea, Somalia, Madagascar, Comoros; and, North Africa-Algeria, Egypt, Tunisia, Sudan (including South Sudan), Morocco, Libya, Western Sahara.

\subsection{Characteristics of Studies Included in the Analysis}

We identified a total of 604 articles from database searches, which were reduced to 500 after the removal of duplicates. Observational studies included for analysis were cross-sectional, prospective, retrospective and case report, which occurred at different settings such as rural, urban or hospital based. Out of the 500 articles, 81 articles met the inclusion criteria and were further analyzed (Figure 1). Some studies reported on multi-country and multi-site studies. One hundred and twenty-six studies on HHV-8 sero-epidemiology or genotypes, published from 1998-2017, were obtained from the 81 articles and met the inclusion criteria for analysis. About $64 \%(81 / 126)$ of the studies were available on HHV-8 seroprevalence; $29.3 \%$ (37/126) were available on HHV-8 genotypes; and 9.5\% (12/126) of the studies were available for both seroprevalence and genotypes. Overall, 52.8\% (28/53) of African countries had data on either seroprevalence or genotypes of HHV-8. Tables S1-S5 (Supplementary Materials) present studies from the different African regions included in the analysis.

\subsection{HHV-8 Seroprevalence Distribution in Africa}

About 45\% (24/53) of African countries had data on HHV-8 seroprevalence only. Bearing in mind that different test strategies were applied in determining seropositivity in different populations, seropositivity reported ranged from $0.0 \%$ in a group of blood donors in Morocco by indirect immunofluorescence [35], through $2.0 \%$ in a group of young children in Eritrea by the detection of antibodies to ORF73 [36], to $100 \%$ in a small group of individuals with KS in the Central Africa Republic using immunofluorescence and immuno-peroxidase assays [37], although in a larger group of individuals with KS in Morocco the prevalence was $92 \%$ by indirect immunofluorescence [35]. Out of the 126 studies, 20 (15.8\%) reported on children, in which seroprevalence ranged from $2 \%$ to $69 \%$. Regionally, the seroprevalence across the continent ranged as follows: Southern Africa (14.0-90.0\%), Central Africa (17.4-100.0\%), West Africa (14.0-83.1\%), East Africa (2.0-93.0\%), and North Africa (0.0-92.0\%). Considering the highest reported seroprevalence from the different African regions, there was no significant difference among the African regions (95\% CI, $\left.\chi^{2}=0.86 ; p=0.35\right)$. Figure 2 represents the relative seroprevalence of HHV-8 across Africa. 


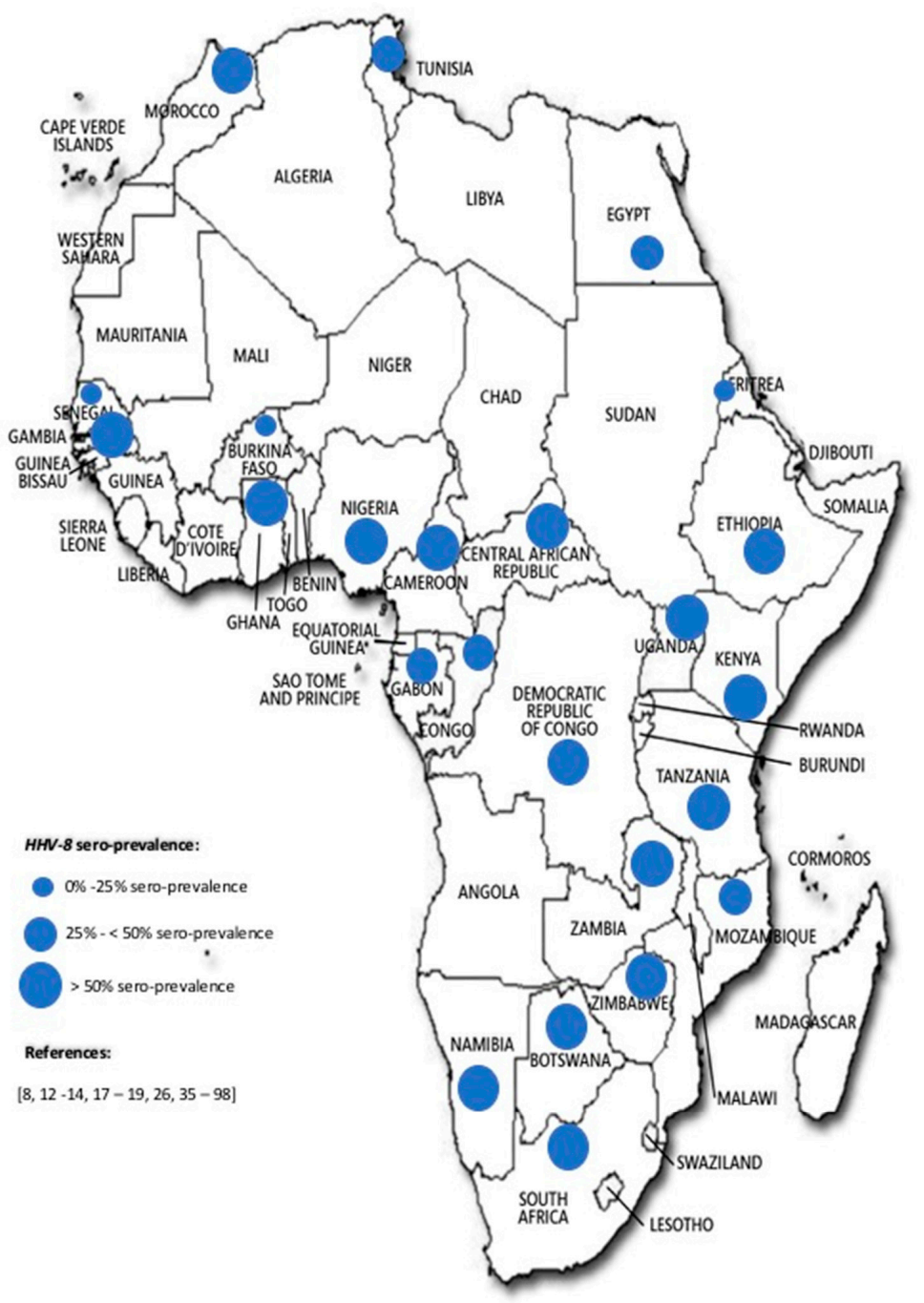

Figure 2. A representation of the highest HHV-8 seroprevalence observed in any one population in African countries (1998-2017). It should be borne in mind that the reported seroprevalences are from studied populations which employed different designs, approaches, populations, tests and interpretation algorithms, even within the same country. Thus, it could be difficult to make direct comparisons between and among studied populations [8,12-14,17-19,26,35-98].

\subsection{A Comparison of HHV-8 Seroprevalence among Selected Populations across African Regions}

From the available data, HHV-8 infection among children was observed to be significantly different across the African regions, with children in Central Africa being the most infected. The burden of infection was also significant in HIV-infected children compared to HIV non-infected children in Southern Africa (Table 1). Across the different African regions, HHV-8 antibodies were generally detected in a higher frequency in non-pregnant women than in pregnant women of comparable age, except in West Africa, were pregnant women were more infected than non-pregnant women (Table 2). No studies meeting the inclusion criteria were available for North Africa. Regarding geographical setting, there is no clear picture on the distribution of HHV-8 between rural and urban populations within and across African regions. For example, the urban population was marginally more infected than the rural population in Southern and East Africa, while this is not the case in West Africa. Across regions, the urban population in West Africa was the most infected. Data for North and Central Africa were inadequate to permit meaningful comparisons (Table 3). 
Table 1. Relative HHV-8 infection burden in children, and proportion of HIV positive, HIV negative, and children with $\mathrm{KS}$ among the child population in Africa.

\begin{tabular}{|c|c|c|c|c|c|c|}
\hline African Region & $\begin{array}{l}\text { Percentage of } \\
\text { Children } \\
\text { Infected with } \\
\text { HHV-8 }\end{array}$ & $\begin{array}{c}\text { Percentage of } \\
\text { HIV Positive } \\
\text { Children } \\
\text { Infected with } \\
\text { HHV-8 of All } \\
\text { Children with } \\
\text { HHV-8 }\end{array}$ & $\begin{array}{c}\text { Percentage of } \\
\text { HIV Negative } \\
\text { Children } \\
\text { Infected with } \\
\text { HHV-8 of All } \\
\text { Children with } \\
\text { HHV-8 }\end{array}$ & $\begin{array}{c}\text { Percentage of } \\
\text { Children with } \\
\text { KS and } \\
\text { Infected with } \\
\text { HHV-8 of All } \\
\text { Children with } \\
\text { HHV-8 }\end{array}$ & $\begin{array}{c}\text { Chi-Square } \\
\text { Value }\end{array}$ & $\begin{array}{c}p \text {-Value } \\
\text { (Significant } \\
\text { at } p \leq 0.05 \text { ) }\end{array}$ \\
\hline Southern & $31.4(342 / 1092)$ & $52.6(180 / 342)$ & $21.1(72 / 342)$ & $26.3(90 / 342)$ & 90.5 & $<0.0015$ \\
\hline Central & $49.5(329 / 665)$ & No data & No data & No data & Not done & Not done \\
\hline West & $11.4(49 / 429)$ & $18.6(80 / 429)$ & $81.3(349 / 429)$ & No data & 128.8 & 0.0001 \\
\hline East & $20.7(945 / 4557)$ & No data & No data & $1.6(15 / 945)$ & Not done & Not done \\
\hline North & $43.3(122 / 282)$ & No data & No data & $5.3(15 / 282)$ & Not done & Not done \\
\hline Chi-square value & 367.2 & 98.3 & 279.1 & 220.0 & 34.9 & 0.401 \\
\hline$p$-value & $<0.00001$ & - & - & - & - & - \\
\hline
\end{tabular}

Data on children described in selected studies were summed up for each region and analysed. The percentages of HIV positive children, HIV negative children, and children with KS are calculated based on the total number of children with HHV-8 pooled from the extracted studies in the different African regions. Data from North Africa were not sufficient for meaningful comparable analysis and were omitted.

Table 2. Relative HHV-8 infection burden in women of comparable age (25-45 years) in Africa.

\begin{tabular}{cccccc}
\hline African Region & $\begin{array}{c}\text { Percentage of } \\
\text { Women Infected } \\
\text { with HHV-8 }\end{array}$ & $\begin{array}{c}\text { Percentage of } \\
\text { Pregnant Women } \\
\text { Infected with } \\
\text { HHV-8 of All } \\
\text { Women with } \\
\text { HHV-8 }\end{array}$ & $\begin{array}{c}\text { Percentage of } \\
\text { Non-Pregnant } \\
\text { Women Infected } \\
\text { with HHV-8 of All } \\
\text { Women with } \\
\text { HHV-8 }\end{array}$ & $\begin{array}{c}\text { Chi-Square } \\
\text { value }\end{array}$ & $\begin{array}{c}p \text {-Value } \\
\text { (Significant at } \\
p \leq \mathbf{0 . 0 5})\end{array}$ \\
\hline Southern & $28.7(4196 / 14,612)$ & $8.2(343 / 4196)$ & $91.8(3853 / 4196)$ & 155.93 & $<0.00001$ \\
\hline Central & $6.2(287 / 4626)$ & $27.5(79 / 287)$ & $72.5(208 / 287)$ & 100.00 & $<0.00001$ \\
\hline West & $1.7(151 / 8491)$ & $61.0(92 / 151)$ & $39.3(59 / 151)$ & 79.20 & 0.00001 \\
\hline East & $26.1(2280 / 8729)$ & $22.2(501 / 2280)$ & $78.0(1779 / 2280)$ & 80.73 & 0.00001 \\
\hline Chi Square value & 41.49 & 72.54 & 41.61 & - & - \\
\hline$p$-value & $<0.00001$ & $<0.0001$ & $<0.00001$ & - & - \\
\hline
\end{tabular}

Data on women described in selected studies were summed up for each region and analysed. The percentages of pregnant and non-pregnant women infected with HHV-8 were calculated based on the total number of women with HHV-8 pooled from the extracted studies in the different African regions. Data from the North Africa region were not sufficient for meaningful comparable analysis and were omitted.

Table 3. Relative HHV-8 infection burden in rural and urban populations in Africa.

\begin{tabular}{ccccc}
\hline African Region & $\begin{array}{c}\text { Percentage of } \\
\text { HHV-8 } \\
\text { Seropositivity in } \\
\text { the Rural Setting }\end{array}$ & $\begin{array}{c}\text { Percentage of } \\
\text { HHV-8 } \\
\text { Seropositivity in } \\
\text { the Urban Setting }\end{array}$ & Chi-Square Value & $\begin{array}{c}p \text {-Value } \\
\text { (Significant at } \\
\boldsymbol{p} \leq \mathbf{0 . 0 5})\end{array}$ \\
\hline Southern & $5.4(207 / 3781)$ & $3.3(191 / 5710)$ & 764.03 & 0.00001 \\
Central & $20.0(516 / 2579)$ & No data & Not done & Not done \\
West & $31.8(77 / 242)$ & $42.0(26 / 62)$ & 2.4462 & 0.119 \\
East & $29.0(829 / 2409)$ & $42.5(450 / 1060)$ & 84.52 & 0.0 \\
Chi Square value & 52.30 & 50.21 & Not done & Not done \\
$p$-value & $<0.00001$ & $<0.0001$ & Not done & Not done \\
\hline
\end{tabular}

Data on the rural and urban populations described in the selected studies were summed up for each region and analysed. Data from the North African region were not sufficient for meaningful comparable analysis and were omitted.

\subsection{HHV-8 Genotype Distribution in Africa}

Based on the K1 gene, 33.9\% (18/53) of African countries had data on genotypes, while $28.3 \%$ $(15 / 53)$ of countries had data on K15 genotypes (Figure 3). Genotypes A, A5, B, C, F and Z were identified at frequencies of 5.3\% (2/38), 26.3\% (10/38), 42.1\% (16/38), 18.4\% (7/38), 5.3\% (2/38) and 
$2.6 \%(1 / 38)$, respectively; genotypes $\mathrm{P}, \mathrm{M}$ and $\mathrm{N}$ of the $\mathrm{K} 15$ gene were identified at frequencies of $52.2 \%$ $(12 / 23), 39.1 \%(9 / 23)$ and 8.7\% (2/23), respectively (Figure 4). Of the 18 countries from which K1 genotypes were reported, at least two genotypes were reported in each. Genotype $Z$ was reported from only one study in Zambia involving children [23]. All other genotypes were reported in both children and adults. From the available data, there appears to be no trend in the distribution of genotypes across the continent. Worthy of note though is the description of K15 genotype N in Southern Africa (South Africa and Zambia) [23,99], and it is not clear whether K15 genotype N is restricted to Southern Africa. Data were reported for a few countries on intra-genotypic variants but data on inter-genotypic recombinants appears to be scanty $[38,39,100,101]$.

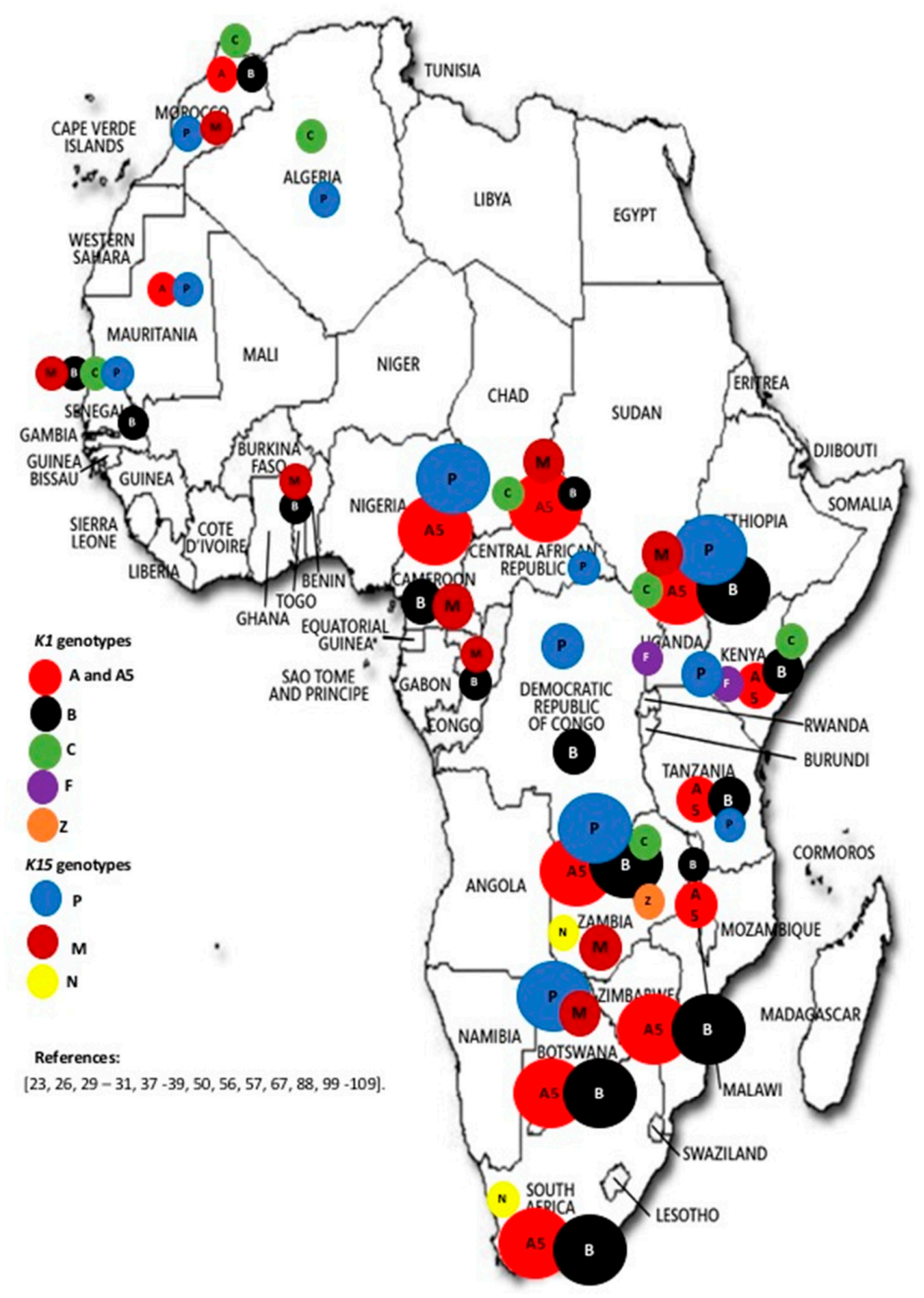

Figure 3. Map of Africa showing the occurrence of HHV-8 genotypes. There appears to be a general distribution of different genotypes across the continent. Of note is the identification of K15 genotype $\mathrm{N}$ in Southern Africa only (Zambia and South Africa). Countries without indications had no published data on HHV-8 genotypes between 1998-2017. The size of the circles indicates the relative proportion of occurrence of the different genotypes in the different countries. Overall, K1 genotypes A5 and B, and K15 genotypes $\mathrm{P}$ and $\mathrm{M}$ are the most common throughout the continent $[23,26,29-31,37-39,42,44$, 50,56,57,67,88,99-109]. 

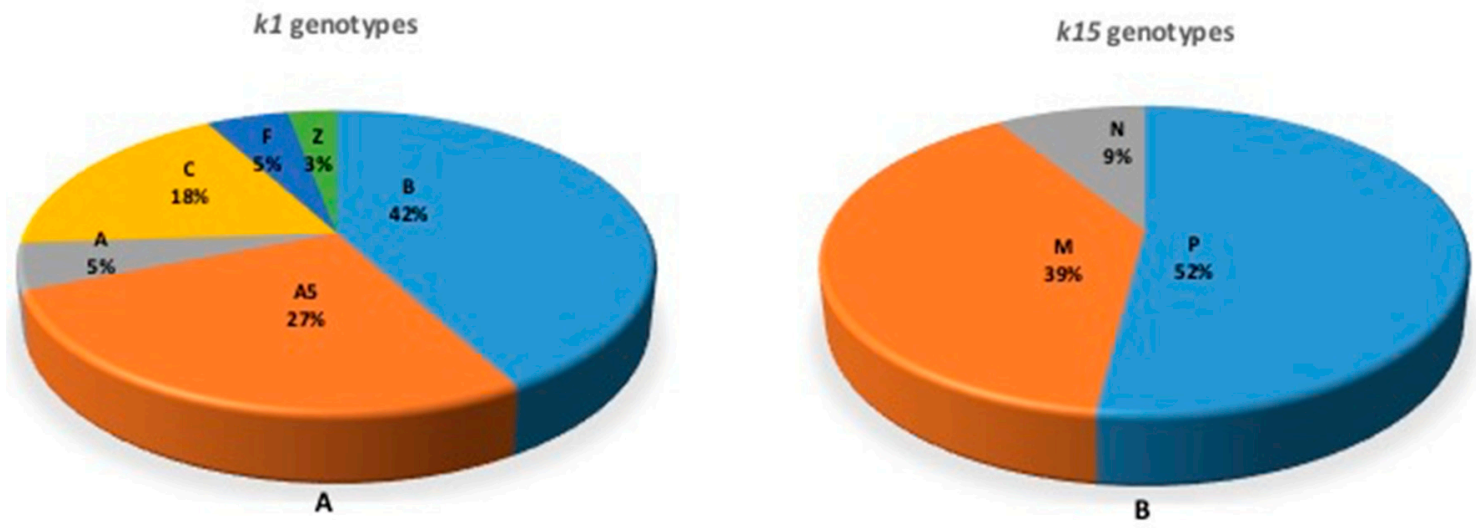

Figure 4. Proportional representation of HHV-8 genotypes in Africa. (A) represents K1 genotypes; (B) represents K15 genotypes. K1 genotype B is the most prevalent followed by genotype A5, while K15 genotype $\mathrm{P}$ is most prevalent genotype followed by genotype $\mathrm{M}$.

\section{Discussion and Conclusions}

Studies on HHV-8 infection are important in regions, such as Africa, where a significant proportion of the continent is infected with immunosuppressive agents, such as HIV. This review was aimed at providing an update on the epidemiology and prevalent genotypes of HHV-8 in Africa. We observed that infection with HHV-8 is generally highly endemic in most parts of Africa, indicating that risk factors for infection persist throughout the continent. Reports suggest that there is variety and non-uniformity in the modes of transmission of HHV-8 among populations in Africa. For example, horizontal transmission from mother to child through chewed food (saliva) and contact with family members $[12,42,89]$ sexual intercourse $[62,65,87]$ other infections such as malaria [83], and blood transfusion $[90,93]$ have been identified as risk factors for transmission. High seropositivity has been shown in pregnant women [64], and it has been suggested that the risk of HHV-8 seropositivity is significantly higher in children of HHV-8 seropositive mothers compared with children of HHV-8 seronegative mothers [110]. Further to this, in a sub-analysis of literature of pregnant and non-pregnant women, we found that in certain regions of Africa HHV-8 seropositivity was more frequent in non-pregnant women than in pregnant women of comparable age, while the converse was true in other regions (for example, in West Africa). This discrepancy or lack of trend may be attributed to other underlying confounding factors in HHV-8 acquisition in the different study populations and regions. Generally, there is a relatively lower rate of infection among children in Africa, which reflects findings that the rate of infection with HHV-8 in a given population increases in older age groups [71]. Most of the countries in Central, Southern and East African regions of the continent harbor huge burdens of HHV-8 infection. Geographic and cultural factors have been proposed as key determinants of HHV-8 transmission in some of these regions [12,53,54], also accounting for the variability in prevalence across and within geographic regions [71]. Additionally, a meta-analysis involving studies undertaken in 32 countries in sub-Saharan Africa, Australia, North and South America, Europe and Asia, demonstrated that HIV-infection is associated with a significant increase in HHV-8 co-infection globally, and in all population groups [111]. This scenario thereby coexists with the high HIV endemicity in Central, East and Southern Africa, and the probability of co-infection is therefore significantly increased in the said populations. Hence, with immunosuppression from HIV infection, it is plausible that cases of Kaposi's sarcoma will rise, although this could be mitigated with the improved access to antiretroviral therapy [45].

Our analysis revealed that HHV-8 genotypes A5 and B based on the $K 1$ gene and genotypes $P$ and M based on the K15 gene are the most prevalent in Africa. Genotype B is associated with endemic KS, while genotype P has been reported to be highly transmissible. Previous reports $[25,27,43]$, indicated the clustering patterns of HHV-8 genotypes with ethnic composition of the population and 
geographical location, and these might have arisen through ancient human migrations and genetic polymorphisms. The classification of HHV-8 into genotypes has not generally followed a unified approach. Some studies have used more than one gene for viral grouping, and some investigators has shown a link between gene regions; for example, [30] reported a link between ORF26 and K1. Intra-genotype variants have also been reported; for example, K1 A5 and K15 M based on allele differences $[38,39,88]$. A5 viruses are closely related to viruses found mostly in viral populations that form the A1-4 genotypes. Previously, A5 was thought to have emerged from recombination. However, subsequent and more robust analyses point to the emergence of the A5 genotype because of natural genetic drift and divergence between A1-4 genotypes [39,65]. It has been hypothesized [28] that the distribution of the K1-A5 genotype in African populations is because of a "very rapid and recent aggressive spread" of the K1-A5 prototype introduced into the population, aided by a selective advantage of the A5 allele. Overall, previous studies have demonstrated the clustering patterns of HHV-8 genotypes with geography and ethnicity, and these may have arisen through ancient human migrations and genetic polymorphisms, respectively $[100,101]$. The current analysis revealed scanty data on inter-genotype recombinants, with two studies reporting on the A/C genotype in Africa $[39,101]$. The A/C genotype is prevalent in Europe, United States, Asia, and the Middle East.

The current analysis, covering the period 1998-2017, suffers from a relative lack of data, dispersed across the continent, from about $50 \%$ of the countries, thereby somewhat limiting our appreciation of the burden of HHV-8 infection. However, the fact that high prevalence was noted in certain countries in all regions of the continent suggests that there is generalized infection across the geographical spectrum of Africa. The findings suggest that the entire continent is endemic for HHV-8, and co-infection with HIV may be common in those African countries endemic for HIV. Noting that there is high heterogeneity in the testing strategies employed in the detection of HHV-8 antibodies, there is need for an acceptable harmonized protocol to enhance the possibility of comparisons of seropositivity across studies. Since genotypes A5, B, P and M are highly prevalent in Africa, it is suggested that full length genomes of these genotypes from Africa be characterized to support the rational selection of genes for the design and development of vaccine candidates. This is, apparently, the first attempt at a systematic review of the seroprevalence and genotype distribution of HHV-8 comprising all African countries.

Supplementary Materials: The following are available online at http:/ / www.mdpi.com/1999-4915/10/9/458/s1. Tables S1-S5: Characteristics of studies included in the systematic review according to regions of Africa.

Author Contributions: P.O.B. conceptualized the study and analysed the data; E.M.E. performed the literature search, analysed the data, and prepared the first draft of the manuscript; D.P.A. performed literature search, analysed the data; L.G.M.-R. prepared the first draft of the manuscript; G.G. analysed the data and criticized the manuscript for intellectual content; all authors read and approved the final version of the manuscript for submission.

Acknowledgments: This work is based on the research supported in part by the National Research Foundation of South Africa (Grant Numbers: 113465, 109312). E.M.E. acknowledges support from the Global Infectious Diseases Research Training Programme of the Fogarty International Center/NIH, USA (D43TW006578); and the Research and Publication Committee of the University of Venda, South Africa. G.G. was supported by award number D43 TW009359 from the Fogarty International Center, National Institutes of Health. The funding organizations had no role in the conception or production of the current work. The opinions expressed here do not necessarily reflect the views of the Fogarty International Center/NIH, USA, or the National Research Foundation, South Africa.

Conflicts of Interest: The authors declare no conflict of interest.

\section{References}

1. Porter, S.R.; Di Alberti, L.; Kumar, N. Human Herpes Virus 8 (Kaposi's Sarcoma Herpesvirus). Oral Oncol. 1998, 34, 5-14. [CrossRef]

2. Centers for Disease Control. Pneumocystis Pneumonia-Los Angeles. Morb. Mortal. Wkly. Rep. 1981, 30, 250-252.

3. Boshoff, C.; Weiss, R.A. Epidemiology and Pathogenesis of Kaposi's Sarcoma-Associated Herpesvirus. Philos. Trans. R. Soc. Lond. B Biol. Sci. 2001, 356, 517-534. [CrossRef] [PubMed] 
4. Cook-Mozaffari, P.; Newton, R.; Beral, V.; Burkitt, D.P. The Geographical Distribution of Kaposi's Sarcoma and of Lymphomas in Africa before the AIDS Epidemic. Br. J. Cancer 1998, 78, 1521-1528. [CrossRef] [PubMed]

5. Doutrelepont, J.M.; De Pauw, L.; Gruber, S.A.; Dunn, D.L.; Qunibi, W.; Kinnaert, P.; Vereerstraeten, P.; Penn, I.; Abramowicz, D. Renal Transplantation Exposes Patients with Previous Kaposi's Sarcoma to a High Risk of Recurrence. Transplantation 1996, 62, 463-466. [CrossRef] [PubMed]

6. Nagy, S.; Gyulai, R.; Kemény, L.; Szenohradszky, P.; Dobozy, A. IATROGENIC KAPOSIS SARCOMA: HHV8 Positivity Persists but the Tumors Regress Almost Completely without Immunosuppressive Therapy 1. Transplantation 2000, 69, 2230-2231. [CrossRef] [PubMed]

7. Fontana, J.M.; Mygatt, J.G.; Conant, K.L.; Parsons, C.H.; Kaleeba, J.A.R. Kaposi's Sarcoma-Associated Herpesvirus Sunversion of the Anti-inflammatory Response in Human Skin Cell Reveal Correlates of Latency and diseases Pathogenesis. J. Skin Cancer 2014, 2014, 246076. [CrossRef] [PubMed]

8. Stolka, K.; Ndom, P.; Hemingway-Foday, J.; Iriondo-Perez, J.; Miley, W.; Labo, N.; Stella, J.; Abassora, M.; Woelk, G.; Ryder, R.; et al. Risk Factors for Kaposi's Sarcoma among HIV-Positive Individuals in a Case Control Study in Cameroon. Cancer Epidemiol. 2014, 38, 137-143. [CrossRef] [PubMed]

9. Traylen, C.M.; Patel, H.R.; Fondaw, W.; Mahatme, S.; Williams, J.F.; Walker, L.R.; Dyson, O.F.; Arce, S.; Akula, S.M. Virus Reactivatio: A panoramic view in human infections. Fut. Med. 2011, 6, 4. [CrossRef]

10. Whitby, D.; Luppi, M.; Sabin, C.; Barozzi, P.; Di Biase, A.R.; Balli, F.; Cucci, F.; Weiss, R.A.; Boshoff, C.; Torelli, G. Detection of Antibodies to Human Herpesvirus 8 in Italian Children: Evidence for Horizontal Transmission. Br. J. Cancer 2000, 82, 702-704. [CrossRef] [PubMed]

11. Mbulaiteye, S.M.; Pfeiffer, R.M.; Engels, E.A; Marshall, V.; Bakaki, P.M.; Owor, A.M.; Ndugwa, C.M.; Katongole-Mbidde, E.; Goedert, J.J.; Biggar, R.J.; et al. Detection of Kaposi Sarcoma-Associated Herpesvirus DNA in Saliva and Buffy-Coat Samples from Children with Sickle Cell Disease in Uganda. J. Infect. Dis. 2004, 190, 1382-1386. [CrossRef] [PubMed]

12. Plancoulaine, S.; Abel, L.; Tregouet, D.; Duprez, R.; Beveren, M.V.; Tortevoye, P.; Froment, A.; Gessai, A. Respective roles of Serological Status and Blood Specific Antihuman Herpesvirus 8 Antibody Levels in Human Herpesvirus 8 Intrfamilial Transmission in a Highly Endemic Area. Cancer Res. 2004, 64, 8782-8787. [CrossRef] [PubMed]

13. Mbondji-Wonje, C.; Ragupathy, V.; Lee, S.; Wood, O.; Awazi, B.; Hewlett, I.K. Seroprevalence of Human Herpesvirus-8 in HIV-1 Infected and Uninfected Individuals in Cameroon. Viruses 2013, 5, 2253-2259. [CrossRef] [PubMed]

14. Sitas, F.; Carrara, H.; Beral, V.; Newton, R.; Reeves, G.; Bull, D.; Jentsch, U.; Pacella-Norman, R.; Bourboulia, D.; Whitby, D.; et al. Antibodies against Human Herpesvirus 8 in Black South African Patients with Cancer. N. Engl. J. Med. 1999, 340, 1863-1871. [CrossRef] [PubMed]

15. Dedicoat, M.; Vaithilingum, M.; Newton, R.R. Treatment of Kaposis Sarcoma in HIV-1 Infected Individuals with Emphasis on Resource Poor Settings. Cochrane Database Syst. Rev. 2003, 8, CD003256. [CrossRef]

16. Facciola, A.; Venanzi Rullo, E.; Ceccarell, M.; Daleo, F.; Dirosa, D.I.; Pinzone, M.R.; Condorelli, F.; Visalli, G.; Picerno, I.; Fisichella, R.; et al. Kaposis's sarcomain HIV-infected patients in the era of new antiretrovirals. Eur. Rev. Med. Pharmacol. Sci. 2017, 21, 5868-5879. [PubMed]

17. Andreoni, M.; El-Sawaf, G.; Rezza, G.; Ensoli, B.; Nicastri, E.; Ventura, L.; Ercoli, L.; Sarmati, L.; Rocchi, G. High Seroprevalence of Antibodies to Human Herpesvirus-8 in Egyptian Children: Evidence of Nonsexual Transmission. J. Natl. Cancer Inst. 1999, 91, 465-469. [CrossRef] [PubMed]

18. Gessain, A.; Mauclère, P.; van Beveren, M.; Plancoulaine, S.; Ayouba, A.; Essame-Oyono, J.L.; Martin, P.M.; de Thé, G. Human Herpesvirus 8 Primary Infection Occurs during Childhood in Cameroon, Central Africa. Int. J. Cancer 1999, 81, 189-192. [CrossRef]

19. Wilkinson, D.; Sheldon, J.; Gilks, C.F.; Schulz, T.F. Prevalence of Infection with Human Herpesvirus 8/Kaposi's Sarcoma Herpesvirus in Rural South Africa. S. Afr. Med. J. 1999, 89, 554-557. [PubMed]

20. Hoffmann, C.; Sabranski, M.; Esser, S. HIV-Associated Kaposi's Sarcoma. Oncol. Res. Treat. 2017, 40, 94-98. [CrossRef] [PubMed]

21. Gulick, R.M.; Wilkin, T.J.; Chen, Y.Q.; Landovitz, R.J.; Amico, K.R.; Young, A.M.; Richardson, P.; Marzinke, M.A.; Hendrix, C.W.; Eshleman, S.H.; et al. Phase 2 Study of the Safety and Tolerability of Maraviroc-Containing Regimens to Prevent HIV Infection in Men Who Have Sex With Men (HPTN 069/ACTG A5305). J. Infect. Dis. 2017, 215, 238-246. [CrossRef] [PubMed] 
22. Schneider, J.W.; Dittmer, D.P. Diagnosis and Treatment of Kaposi Sarcoma. Am. J. Clin. Dermatol. 2017, 18, 529-539. [CrossRef] [PubMed]

23. Kasolo, F.C.; Monze, M.; Obel, N.; Anderson, R.A.; French, C.; Compels, U.A. Sequence Analyses of Human Herpesvirus-8 Strains from Both African Human Immunodeficiency Virus-Negative and -Positive Childhood Endemic Kaposi's Sarcoma Show a Close Relationship with Strains Identified in Febrile Children and High Variation in the K1 Gl. J. Gen. Virol. 1998, 79, 3055-3065. [CrossRef] [PubMed]

24. Biggar, R.J.; Whitby, D.; Marshall, V.; Linhares, A.C.; Black, F. Human Herpesvirus 8 in Brazilian Amerindians: A Hyperendemic Population with a New Subtype. J. Infect. Dis. 2000, 181, 1562-1568. [CrossRef] [PubMed]

25. Meng, Y.X.; Sata, T.; Stamey, F.R.; Voevodin, A.; Katano, H.; Koizumi, H.; Deleon, M.; De Cristofano, M.A.; Galimberti, R.; Pellett, P.E. Molecular Characterization of Strains of Human Herpesvirus 8 from Japan, Argentina and Kuwait. J. Gen. Virol. 2001, 82, 499-506. [CrossRef] [PubMed]

26. Whitby, D.; Marshall, V.A.; Bagni, R.K.; Wang, C.D.; Gamache, C.J.; Guzman, J.R.; Kron, M.; Ebbesen, P.; Biggar, R.J. Genotypic Characterization of Kaposi's Sarcoma-Associated Herpesvirus in Asymptomatic Infected Subjects from Isolated Populations. J. Gen. Virol. 2004, 85, 155-163. [CrossRef] [PubMed]

27. Cassar, O.; Afonso, P.V.; Bassot, S.; Plancoulaine, S.; Duprez, R.; Capuano, C.; Abel, M.; Martin, P.M.V.; Gessain, A. Novel Human Herpesvirus 8 Subtype D Strains in Vanuatu, Melanesia. Emerg. Infect. Dis. 2007, 13, 1745-1748. [CrossRef] [PubMed]

28. Hayward, G.S.; Zong, J.C. Modern Evolutionary History of the Human KSHV Genome. Curr. Top. Microbiol. Immunol. 2007, 312, 1-42. [PubMed]

29. White, T.; Hagen, M.; Gudza, I.; White, I.E.; Ndemera, B.; Gwanzura, L.; Borok, M.; Campbell, T.B. Genetic Diversity of the Kaposi's Sarcoma Herpesvirus K1 Protein in AIDS-KS in Zimbabwe. J. Clin. Virol. 2008, 42, 165-171. [CrossRef] [PubMed]

30. Tornesello, M.L.; Biryahwaho, B.; Downing, R.; Hatzakis, A.; Alessi, E.; Cusini, M.; Ruocco, V.; Katongole-Mbidde, E.; Loquercio, G.; Buonaguro, L.; et al. Human Herpesvirus Type 8 Variants Circulating in Europe, Africa and North America in Classic, Endemic and Epidemic Kaposi's Sarcoma Lesions during Pre-AIDS and AIDS Era. Virology 2010, 398, 280-289. [CrossRef] [PubMed]

31. Isaacs, T.; Abera, A.B.; Muloiwa, R.; Katz, A.A.; Todd, G. Genetic Diversity of HHV8 Subtypes in South Africa: A5 Subtype Is Associated with Extensive Disease in AIDS-KS. J. Med. Virol. 2016, 88, 292-303. [CrossRef] [PubMed]

32. Wu, T.T.; Qian, J.; Ang, J.; Sun, R. Vaccine prospect of Kaposi sarcoma-associated herpesviruses. Cur. Opin. Virol. 2012, 2, 482-488. [CrossRef] [PubMed]

33. Coen, N.; Duraffour, S.; Snoeck, R.; Andrei, G. KSHV Target Therapy: An update on inhibitors of viral lytic replication. Viruses 2014, 6, 4731-4759. [CrossRef] [PubMed]

34. Riva, G.; Luppi, M.; Barozzi, P.; Forghieri, F.; Potenza, L. How I Treat HHV8/KSHV-Related Diseases in Posttransplant Patients. Blood 2012, 120, 4150-4159. [CrossRef] [PubMed]

35. El Kassimi, B.; Benchemsi, N.; Mikou, O.; El Ouazzani, T.; Lakhdar, H. Maladie de Kaposi et Anticorps Anti-Herpès Virus-8 Au Maroc. Med. Mal. Infect. 2003, 33, 226-228. [CrossRef]

36. Enbom, M.; Tolfvenstam, T.; Ghebrekidan, H.; Rudén, U.; Grandien, M.; Wahren, B.; Linde, A. Seroprevalence of Human Herpes Virus 8 in Different Eritrean Population Groups. J. Clin. Virol. 1999, 14, 167-172. [CrossRef]

37. Fouchard, N.; Lacoste, V.; Couppie, P.; Develoux, M.; Mauclere, P.; Michel, P.; Herve, V.; Pradinaud, R.; Bestetti, G.; Huerre, M.; et al. Detection and Genetic Polymorphism of Human Herpes Virus Type 8 in Endemic or Epidemic Kaposi's Sarcoma from West and Central Africa, and South America. Int. J. Cancer 2000, 85, 166-170. [CrossRef]

38. Poole, L.J.; Zong, J.C.; Cuifo, D.M.; Alcendor, D.J.; Cannon, J.S.; Ambinder, R.; Orenstein, J.M.; Reitz, M.S.; Hayward, G.S. Comparison of Genetic Variabilty at Miltiple Loci across the Genome of the Major Subtypes of Kaposi's Sarcoma Associated Herpes Virus Reveals Evidence for Recombination and for Two Distinct Types of Open Reading Frames K15 Alleles at the Right-Hand End. J. Virol. 1999, 73, 6646-6660. [PubMed]

39. Betsem, E.; Cassar, O.; Afonso, P.V.; Fontanet, A.; Froment, A.; Gessain, A. Epidemiology and Genetic Variability of HHV-8/KSHV in Pygmy and Bantu Populations in Cameroon. PLoS Negl. Trop. Dis. 2014, 8, 5. [CrossRef] [PubMed]

40. Simbiri, K.O.; Jha, H.C.; Kayembe, M.K.; Kovarik, C.; Robertson, E.S. Oncogenic Viruses Associated with Vulva Cancer in HIV-1 Patients in Botswana. Infect. Agents Cancer 2014, 9, 1-28. [CrossRef] [PubMed] 
41. Engels, E.A.; Sinclair, M.D.; Biggar, R.J.; Whitby, D.; Ebbesen, P.; Goedert, J.J.; Gastwirth, J.L. Latent Class Analysis of Human Herpesvirus 8 Assay Performance and Infection Prevalence in Sub-Saharan Africa and Malta. Int. J. Cancer 2000, 88, 1003-1008. [CrossRef]

42. Kasolo, F.C.; Spinks, J.; Bima, H.; Bates, M.; Gompels, U.A. Diverse Genotypes of Kaposi's Sarcoma Associated Herpesvirus (KSHV) Identified in Infant Blood Infections in African Childhood-KS and HIV/AIDS Endemic Region. J. Med. Virol. 2007, 79, 1555-1561. [CrossRef] [PubMed]

43. Wojcicki, J.; Mwanahamuntu, M.; Minhas, V.; Djokic, B.; Kankasa, C.; Klaskala, W.; Brayfield, B.; Phiri, S.; Wood, C.; Mitchell, C.D. Mortality among HIV-1- and Human Herpesvirus Type 8-Affected Mother-Infant Pairs in Zambia. Cancer Epidemiol. Biol. Prev. 2008, 17, 2238-2243. [CrossRef] [PubMed]

44. Ablashi, D.; Chatlynne, L.; Cooper, H.; Thomas, D.; Yadav, M.; Norhanom, A.W.; Chandana, A.K.; Churdboonchart, V.; Kulpradist, S.A.R.; Patnaik, M.; et al. Seroprevalence of Human Herpesvirus-8 (HHV-8) in Countries of Southeast Asia Compared to the USA, the Caribbean and Africa. Br. J. Cancer 1999, 81, 893-897. [CrossRef] [PubMed]

45. He, J.; Bhat, G.; Kankasa, C.; Chintu, C.; Mitchell, C.; Duan, W.; Wood, C. Seroprevalence of Human Herpesvirus 8 among Zambian Women of Childbearing Age without Kaposi's Sarcoma (KS) and Mother-Child Pairs with KS. J. Infect. Dis. 1998, 178, 1787-1790. [CrossRef] [PubMed]

46. Olp, L.N.; Jeanniard, A.; Marimo, C.; West, J.T.; Wood, C. Whole-Genome Sequencing of Kaposi's Sarcoma-Associated Herpesvirus from Zambian Kaposi's Sarcoma Biopsy Specimens Reveals Unique Viral Diversity. J. Virol. 2015, 89, 12299-12308. [CrossRef] [PubMed]

47. Olp, L.N.; Shea, D.M.; White, M.K.; Gondwe, C.; Kankasa, C.; Wood, C. Early Childhood Infection of Kaposi's Sarcoma-Associated Herpesvirus in Zambian Households: A Molecular Analysis. Int. J. Cancer 2013, 132, 1182-1190. [CrossRef] [PubMed]

48. Naniche, D.; Letang, E.; Nhampossa, T.; David, C.; Menendez, C.; Alonso, P. Alterations in T Cell Subsets in Human Immunodeficiency Virus-Infected Adults with Co-Infections in Southern Mozambique. Am. J. Trop. Med. Hyg. 2011, 85, 776-781. [CrossRef] [PubMed]

49. Caterino-de-Araujo, A.; Manuel, R.C.R.; Del Bianco, R.; Santos-Fortuna, E.; Magri, M.C.; Silva, J.M.K.; Bastos, R. Seroprevalence of Human Herpesvirus 8 Infection in Individuals from Health Care Centers in Mozambique: Potential for Endemic and Epidemic Kaposi's Sarcoma. J. Med. Virol. 2010, 82, 1216-1223. [CrossRef] [PubMed]

50. Butler, L.M.; Dorsey, G.; Hladik, W.; Rosenthal, P.J.; Brander, C.; Neilands, T.B.; Mbisa, G.; Whitby, D.; Kiepiela, P.; Mosam, A.; et al. Kaposi Sarcoma-Associated Herpesvirus (KSHV) Seroprevalence in Population-Based Samples of African Children: Evidence for at Least 2 Patterns of KSHV Transmission. J. Infect. Dis. 2009, 200, 430-438. [CrossRef] [PubMed]

51. Maskew, M.; MacPhail, A.; Whitby, D.; Egger, M.; Wallis, C.L.; Fox, M.P. Prevalence and Predictors of Kaposi Sarcoma Herpes Virus Seropositivity: A Cross-Sectional Analysis of HIV-Infected Adults Initiating ART in Johannesburg, South Africa. Infect. Agents Cancer 2011, 6, 1-22. [CrossRef] [PubMed]

52. Bohlius, J.; Maskew, M.; Davies, M.A.; Egger, M. HHV-8 Seroprevalence in HIV-Positive and HIVNegative Populations. Int. J. Cancer 2015, 136, 1243. [CrossRef] [PubMed]

53. Malope, B.I.; MacPhail, P.; Mbisa, G.; MacPhail, C.; Stein, L.; Ratshikhopha, E.M.; Ndhlovu, L.; Sitas, F.; Whitby, D. No Evidence of Sexual Transmission of Kaposi's Sarcoma Herpes Virus in a Heterosexual South African Population. Aids 2008, 22, 519-526. [CrossRef] [PubMed]

54. Malope-Kgokong, B.I.; MacPhail, P.; Mbisa, G.; Ratshikhopha, E.; Maskew, M.; Stein, L.; Sitas, F.; Whitby, D. Kaposi's Sarcoma Associated-Herpes Virus (KSHV) Seroprevalence in Pregnant Women in South Africa. Infect. Agent Cancer 2010, 5, 1-14. [CrossRef] [PubMed]

55. Wojcicki, J.M.; Newton, R.; Urban, M.I.; Stein, L.; Hale, M.; Patel, M.; Ruff, P.; Sur, R.; Bourboulia, D.; Sitas, F. Low Socioeconomic Status and Risk for Infection with Human Herpesvirus 8 among HIV-1 Negative, South African Black Cancer Patients. Epidemiol. Infect. 2004, 132, 1191-1197. [CrossRef] [PubMed]

56. Lampinen, T.M.; Kulasingam, S.; Min, J.; Borok, M.; Gwanzura, L.; Lamb, J.; Mahomed, K.; Woelk, G.B.; Strand, K.B.; Bosch, M.L.; et al. Detection of Kaposi's Sarcoma-Associated Herpesvirus in Oral and Genital Secretions of Zimbabwean Women. J. Infect. Dis. 2000, 181, 1785-1790. [CrossRef] [PubMed]

57. Chokunonga, E.; Levy, L.M.; Bassett, M.T.; Mauchaza, B.G.; Thomas, D.B.; Parkin, D.M. Cancer Incidence in the African Population of Harare, Zimbabwe: Second Results from the Cancer Registry 1993-1995. Int. J. Cancer 2000, 85, 54-59. [CrossRef] 
58. DeSantis, S.M.; Pau, C.P.; Archibald, L.K.; Nwanyanwu, O.C.; Kazembe, P.N.; Dobbie, H.; Jarvis, W.R.; Jason, J. Demographic and Immune Correlates of Human Herpesvirus 8 Seropositivity in Malawi, Africa. Int. J. Infect. Dis. 2002, 6, 266-271. [CrossRef]

59. Nkiki, B.J.; Ndom, P.; Mupang, L.; Agokeng, D.S. Séroprévalence Du Virus de L'herpès Humain-8 Chez Des Patients VIH Positif À L’hôpital Général de Yaoundé-Cameroun. Pan. Afr. Med. J. 2015, 20, 1-7. [CrossRef] [PubMed]

60. Serraino, D.; Toma, L.; Andreoni, M.; Buttò, S.; Tchangmena, O.; Sarmati, L.; Monini, P.; Franceschi, S.; Ensoli, B.; Rezza, G. A Seroprevalence Study of Human Herpesvirus Type 8 (HHV8) in Eastern and Central Africa and in the Mediterranean Area. Eur. J. Epidemiol. 2001, 17, 871-876. [CrossRef] [PubMed]

61. Bender Ignacio, R.A.; Goldman, J.D.; Magaret, A.S.; Selke, S.; Huang, M.L.; Gantt, S.; Johnston, C.; Phipps, W.T.; Schiffer, J.T.; Zuckerman, R.A.; et al. Patterns of Human Herpesvirus-8 Oral Shedding among Diverse Cohorts of Human Herpesvirus-8 Seropositive Persons. Infect. Agents Cancer 2016, 11, 1-7. [CrossRef] [PubMed]

62. De-Thé, G.; Bestetti, G.; van Beveren, M.; Gessain, A. Prevalence of Human Herpesvirus 8 Infection before the Acquired Immunodeficiency Disease Syndrome Related of Kaposi's Sarcoma in East Africa. J. Natl. Cancer Inst. 1999, 91, 1888-1889. [CrossRef] [PubMed]

63. Rezza, G.; Tchangmena, O.B.; Andreoni, M.; Bugarini, R.; Toma, L.; Bakary, D.K.; Glikoutou, M.; Sarmati, L.; Monini, P.; Pezzotti, P.; et al. Prevalence and Risk Factors for Human Herpesvirus 8 Infection in Northern Cameroon. Sex. Transm. Dis. 2000, 27, 159-164. [CrossRef] [PubMed]

64. Bestetti, G.; Renon, G.; Mauclere, P.; Ruffie, A.; Eme, D.; Parravicini, C.; Corbellino, M.; Gessain, A. High Seroprevalence of Human Herpesvirus in Pregnant Women and Prostitutes from Cameroon. Aids 1998, 12, 541-543. [PubMed]

65. Duprez, R.; Kassa-Kelembho, E.; Plancoulaine, S.; Briere, J.; Fossi, M.; Kobangue, L.; Minsart, P.; Huerre, M.; Gessain, A. Human Herpesvirus 8 Serological Markers and Viral Load in Patients with AIDS-Associated Kaposi's Sarcoma in Central Africa Republic. J. Clin. Microbiol. 2005, 43, 4840-4843. [CrossRef] [PubMed]

66. Capan-Melser, M.; Mombo-Ngoma, G.; Akerey-Diop, D.; Basra, A.; Manego-Zoleko, R.; Würbel, H.; Lötsch, F.; Groger, M.; Skoll, M.; Schwing, J.; et al. Epidemiology of Human Herpes Virus 8 in Pregnant Women and Their Newborns-A Cross-Sectional Delivery Survey in Central Gabon. Int. J. Infect. Dis. 2015, 39, 16-19. [CrossRef] [PubMed]

67. Zong, J.C.; Ciufo, D.M.; Alcendor, D.J.; Wan, X.; Nicholas, J.; Browning, P.J.; Rady, P.L.; Tyring, S.K.; Orenstein, J.M.; Rabkin, C.S.; Su, I.J.; et al. High-level variability in the ORF-K1 membrane protein gene at the left end of the Kaposi's sarcoma-associated herpesvirus genome defines four major virus subtypes and multiple variants or clades in different human populations. J. Virol. 1999, 73, 4156-4170. [PubMed]

68. Ukonu, B.A.; Eke, E.U.; Onunu, A.N. Comparison of Prevalence of Kaposi's Sarcoma in HHV-8+ and HHV-8-HIVInfected Patients in South-South Nigeria. J. Sci. Heal. 2011, 3, 185-188. [CrossRef]

69. De Sanjose, S.; Mbisa, G.; Perez-Alvarez, S.; Benavente, Y.; Sukvirach, S.; Hieu, N.T.; Shin, H.; Anh, P.T.H.; Thomas, J.; Lazcano, E.; et al. Geographic Variation in the Prevalence of Kaposi Sarcoma-Associated Herpesvirus and Risk Factors for Transmission. J. Infect. Dis. 2009, 199, 1449-1456. [CrossRef] [PubMed]

70. Ogoina, D.; Onyemelukwe, G.; Musa, B.O.; Babadoko, A. Seroprevalence and Determinants of Human Herpes Virus 8 Infection in Adult Nigerians with and without HIV-1 Infection. Afr. Health Sci. 2011, 11, 158-162. [PubMed]

71. Pfeiffer, R.M.; Wheeler, W.A.; Mbisa, G.; Whitby, D.; Goedert, J.J.; de Thé, G.; Mbulaiteye, S.M. Geographic Heterogeneity of Prevalence of the Human Herpesvirus 8 in Sub-Saharan Africa: Clues about Etiology. Ann. Epidemiol. 2010, 20, 958-963. [CrossRef] [PubMed]

72. Simpore, J.; Granato, M.; Santarelli, R.; Nsme, R.A.A.; Coluzzi, M.; Pietra, V.; Pignatelli, S.; Bere, A.; Faggioni, A.; Angeloni, A. Prevalence of Infection by HHV-8, HIV, HCV and HBV among Pregnant Women in Burkina Faso. J. Clin. Virol. 2004, 31, 78-80. [CrossRef] [PubMed]

73. Collenberg, E.; Ouedraogo, T.; Ganamé, J.; Fickenscher, H.; Kynast-Wolf, G.; Becher, H.; Kouyaté, B.; Kräusslich, H.G.; Sangaré, L.; Tebit, D.M. Seroprevalence of Six Different Viruses among Pregnant Women and Blood Donors in Rural and Urban Burkina Faso: A Comparative Analysis. J. Med. Virol. 2006, 78, 683-692. [CrossRef] [PubMed] 
74. Ariyoshi, K.; van der Loeff Schim, M.; Cook, P.; Whitby, D.; Corrah, T.; Jaffar, S.; Cham, F.; Sabally, S.D.; O'donovan, D.; Weiss, R.A.; et al. Kaposi's Sarcoma in the Gambia, West Africa Is Less Frequent in Human Immunodeficiency Virus Type 2 than in Human Immunodeficiency Type 1 Infection despite a High Prevalence of Human Herpesvirus 8. J. Hum. Virol. 1998, 1, 185-186.

75. Aidoo, S.; Ampofo, W.K.; Brandful, J.A.M.; Nuvor, S.V.; Ansah, J.K.; Nii-Trebi, N.; Barnor, J.S.; Apeagyei, F.; Sata, T.; Ofori-Adjei, D.; et al. Suitability of a Rapid Immunochromatographic Test for Detection of Antibodies to Human Immunodeficiency Virus in Ghana, West Africa. J. Clin. Microbiol. 2001, 39, 2572-2575. [CrossRef] [PubMed]

76. Adjei, A.A.; Armah, H.B.; Gbagbo, F.; Boamah, I.; Adu-Gyamfi, C.; Asare, I. Seroprevalence of HHV-8, CMV, and EBV among the General Population in Ghana, West Africa. BMC Infect. Dis. 2008, 8, 111. [CrossRef] [PubMed]

77. Gaye-Diallo, A.; Toure, A.T.; Gessain, A.; Gueye-Ndiaye, A.; Ndour, A.N.; Toure-Kane, N.C.; Dia, M.C.; de The, G.; Mboup, S. Preliminary Study of Human Herpesvirus Type 8 Infection in Pregnant Women in Dakar (Senegal). Bull. Soc. Pathol. Exot. 2001, 94, 231-234. [PubMed]

78. Mwakigonja, A.R.; Pak, F.; Pyakurel, P.; Mosha, I.J.; Urassa, W.K.; Kaaya, E.E.; Biberfeld, P. Oral Kaposi's Sarcoma in Tanzania: Presentation, Immunopathology and Human Herpesvirus-8 Association. Oncol. Rep. 2007, 17, 1291-1299. [CrossRef] [PubMed]

79. Mbulaiteye, S.M.; Pfeiffer, R.M.; Whitby, D.; Brubaker, G.R.; Shao, J.; Biggar, R.J. Human Herpesvirus 8 Infection within Families in Rural Tanzania. J. Infect. Dis. 2003, 187, 1780-1785. [CrossRef] [PubMed]

80. Lavreys, L.; Chohan, B.; Ashley, R.; Richardson, B.A.; Corey, L.; Mandaliya, K.; Ndinya-Achola, J.O.; Kreiss, J.K. Human Herpesvirus 8: Seroprevalence and Correlates in Prostitutes in Mombasa, Kenya. J. Infect. Dis. 2003, 187, 359-363. [CrossRef] [PubMed]

81. Chohan, B.H.; Taylor, H.; Obrigewitch, R.; Lavreys, L.; Richardson, B.A.; Mandaliya, K.; Bwayo, J.J.; Kreiss, J.K.; Morrow, R.A. Human Herpesvirus 8 Seroconversion in Kenyan Women by Enzyme-Linked Immunosorbent Assay and Immunofluorescence Assay. J. Clin. Virol. 2004, 30, 137-144. [CrossRef] [PubMed]

82. Baeten, J.M.; Chohan, B.H.; Lavreys, L.; Rakwar, J.P.; Ashley, R.; Richardson, B.A.; Mandaliya, K.; Bwayo, J.J.; Kreiss, J.K. Correlates of Human Herpesvirus 8 Seropositivity among Heterosexual Men in Kenya. Aids 2002, 16, 2073-2078. [CrossRef] [PubMed]

83. Taylor, M.M.; Chohan, B.; Lavreys, L.; Hassan, W.; Huang, M.-L.; Corey, L.; Ashley Morrow, R.; Richardson, B.A.; Mandaliya, K.; Ndinya-Achola, J.; et al. Shedding of Human Herpesvirus 8 in Oral and Genital Secretions from HIV-1-Seropositive and -Seronegative Kenyan Women. J. Infect. Dis. 2004, 190, 484-488. [CrossRef] [PubMed]

84. Senba, M.; Buziba, N.; Mori, N.; Morimoto, K.; Nakamura, T. Increased Prevalence of Kaposi's Sarcoma-Associated Herpesvirus in the Kaposi's Sarcoma-Endemic Area of Western Kenya in 1981-2000. Acta Virol. 2011, 55, 161-164. [CrossRef] [PubMed]

85. Mayama, S.; Cuevas, L.E.; Sheldon, J.; Omar, O.H.; Smith, D.H.; Okong, P.; Silvel, B.; Hart, C.A.; Schulz, T.F. Prevalence and Transmission of Kaposi's Sarcoma-Associated Herpesvirus (Human Herpesvirus 8) in Ugandan Children and Adolescents. Int. J. Cancer 1998, 77, 817-820. [CrossRef]

86. Wawer, M.J.; Eng, S.M.; Serwadda, D.; Sewankambo, N.K.; Kiwanuka, N.; Li, C.; Gray, R.H. Prevalence of Kaposi Sarcoma-Associated Herpesvirus Compared with Selected Sexually Transmitted Diseases in Adolescents and Young Adults in Rural Rakai District, Uganda. Sex. Transm. Dis. 2001, 28, 77-81. [CrossRef] [PubMed]

87. Nalwoga, A.; Cose, S.; Wakeham, K.; Miley, W.; Ndibazza, J.; Drakeley, C.; Elliott, A.; Whitby, D.; Newton, R. Association between Malaria Exposure and Kaposi's Sarcoma-Associated Herpes Virus Seropositivity in Uganda. Trop. Med. Int. Heal. 2015, 20, 665-672. [CrossRef] [PubMed]

88. Kakoola, D.N.; Sheldon, J.; Byabazaire, N.; Bowden, R.J.; Katongole-Mbidde, E.; Schulz, T.F.; Davison, A.J. Recombination in Human Herpesvirus-8 Strains from Uganda and Evolution of the K15 Gene. J. Gen. Virol. 2001, 82, 2393-2404. [CrossRef] [PubMed]

89. Shebl, F.M.; Dollard, S.C.; Pfeiffer, R.M.; Biryahwaho, B.; Amin, M.M.; Munuo, S.S.; Hladik, W.; Parsons, R.; Graubard, B.I.; Mbulaiteye, S.M. Human Herpesvirus 8 Seropositivity among Sexually Active Adults in Uganda. PLoS ONE 2011, 6. [CrossRef] [PubMed] 
90. Wakeham, K.; Webb, E.L.; Sebina, I.; Muhangi, L.; Miley, W.; Johnson, W.T.; Ndibazza, J.; Elliott, A.M.; Whitby, D.; Newton, R. Parasite Infection Is Associated with Kaposi's Sarcoma Associated Herpesvirus (KSHV) in Ugandan Women. Infect. Agent Cancer 2011, 6, 15. [CrossRef] [PubMed]

91. Biryahwaho, B.; Dollard, S.C.; Pfeiffer, R.M.; Shebl, F.M.; Munuo, S.; Amin, M.M.; Hladik, W.; Parsons, R.; Mbulaiteye, S.M. Sex and Geographic Patterns of Human Herpesvirus 8 Infection in a Nationally Representative Population-Based Sample in Uganda. J. Infect. Dis. 2010, 202, 1347-1353. [CrossRef] [PubMed]

92. Mbulaiteye, S.M.; Pfeiffer, R.M.; Dolan, B.; Tsang, V.C.W.; Noh, J.; Mikhail, N.N.H.; Abdel-Hamid, M.; Hashem, M.; Whitby, D.; Strickland, G.T.; et al. Seroprevalence and Risk Factors for Human Herpesvirus 8 Infection, Rural Egypt. Emerg. Infect. Dis. 2008, 14, 586-591. [CrossRef] [PubMed]

93. Grossman, Z.; Iscovich, J.; Schwartz, F.; Azizi, E.; Klepfish, A.; Schattner, A.; Sarid, R. Absence of Kaposi Sarcoma among Ethiopian Immigrants to Israel despite High Seroprevalence of Human herpesvirus 8. Mayo. Clin. Proc. 2002, 77, 905-909. [CrossRef]

94. Lemma, E.; Constantine, N.T.; Kassa, D.; Messele, T.; Mindaye, T.; Taye, G.; Abebe, A.; Tamene, W.; Tebje, M.; Gebremeskel, W.; et al. Human Herpesvirus 8 Infection in HIV-1-Infected and Uninfected Pregnant Women in Ethiopia. Ethiop. Med. J. 2009, 47, 205-211. [PubMed]

95. Andreoni, M.; Sarmati, L.; Nicastri, E.; El Sawaf, G.; El Zalabani, M.; Uccella, I.; Bugarini, R.; Parisi, S.G.; Rezza, G. Primary Human Herpesvirus 8 Infection in Immunocompetent Children. Jama 2002, 287, 1295-1300. [CrossRef] [PubMed]

96. Lahlaoui, H.; Niija, H.; Ben Moussa, M. Seroprevalence of Human Herpesvirus 8 in Kidney Transplant Recipients in a Single-Center Study from Tunisia. Iran J. Kid. Dis. 2012, 6, 14-16.

97. Hannachi, N.; Ben Fredj, N.; Samoud, S.; Ferjani, A.; Khlif, A.; Boughammoura, L.; Soussi, S.; Aouni, M.; Skouri, H.; Boukadida, J. Séroprévalence et Facteurs de Risque de L'infection Par Le Virus Herpès Humain 8 Dans Le Centre-Est Tunisien. Pathol. Biol. 2012, 60, 282-286. [CrossRef] [PubMed]

98. Kissi, Y.E.; Hannach, N.; Gaabout, S.; Samoud, S.; Ayachi, M.; Boukadida, J.; Ali, B.H. High Prevalence of Human Herpesvirus 8 in a Tunisian Sample of Schizophrenic Patients. J. Eur. Psychiatr. Assoc. 2011, 26, 1375. [CrossRef]

99. Alagiozoglou, L.; Sitas, F.; Morris, L. Phylogenetic Analysis of Human Herpesvirus-8 in South Africa and Identification of a Novel Subgroup. J. Gen. Virol. 2000, 81, 2029-2038. [CrossRef] [PubMed]

100. Zong, J.; Ciufo, D.M.; Viscidi, R.; Alagiozoglou, L.; Tyring, S.; Rady, P.; Orenstein, J.; Boto, W.; Kalumbuja, H.; Romano, N.; et al. Genotypic Analysis at Multiple Loci across Kaposi's Sarcoma Herpesvirus (KSHV) DNA Molecules: Clustering Patterns, Novel Variants and Chimerism. J. Clin. Virol. 2001, 23, 119-148. [CrossRef]

101. Lacoste, V.; Judde, J.G.; Brière, J.; Tulliez, M.; Garin, B.; Kassa-Kelembho, E.; Morvan, J.; Couppié, P.; Clyti, E.; Forteza Vila, J.; et al. Molecular Epidemiology of Human Herpesvirus 8 in Africa: Both B and A5 K1 Genotypes, as Well as the M and P Genotypes of K14.1/K15 Loci, Are Frequent and Widespread. Virology 2000, 278, 60-74. [CrossRef] [PubMed]

102. Olsen, S.J.; Chang, Y.; Moore, P.S.; Biggar, R.J.; Melbye, M. Increasing Kaposi's Sarcoma-Associated Herpesvirus Seroprevalence with Age in a Highly Kaposi's Sarcoma Endemic Region, Zambia in 1985. Aids 1998, 12, 1921-1925. [CrossRef] [PubMed]

103. Campbell, T.B.; Borok, M.; White, I.E.; Gudza, I.; Ndemera, B.; Taziwa, A.; Weinberg, A.; Gwanzura, L. Relationship of Kaposi Sarcoma (KS)-Associated Herpesvirus Viremia and KS Disease in Zimbabwe. Clin. Infect. Dis. 2003, 36, 1144-1151. [CrossRef] [PubMed]

104. Beyari, M.M.; Hodgson, T.A.; Kondowe, W.; Molyneux, E.M.; Scully, C.M.; Porter, S.R.; Teo, C.G. Genotypic Profile of Human Herpesvirus 8 (Kaposi's Sarcoma-Associated Herpesvirus) in Urine. J. Clin. Microbiol. 2004, 42, 3313-3316. [CrossRef] [PubMed]

105. Cook, P.M.; Whitby, D.; Calabro, M.L.; Luppi, M.; Kakoola, D.N.; Hjalgrim, H.; Ariyoshi, K.; Ensoli, B.; Davison, A.J.; Schulz, T.F. Variability and Evolution of Kaposi's Sarcoma-Associated Herpesvirus in Europe and Africa. International Collaborative Group. Aids 1999, 13, 1165-1176. [CrossRef] [PubMed]

106. Meng, Y.X.; Spira, T.J.; Bhat, G.J.; Birch, C.J.; Druce, J.D.; Edlin, B.R.; Edwards, R.; Gunthel, C.; Newton, R.; Stamey, F.R.; et al. Individuals from North America, Australasia, and Africa Are Infected with Four Different Genotypes of Human Herpesvirus 8. Virology 1999, 261, 106-119. [CrossRef] [PubMed] 
107. Kajumbula, H.; Wallace, R.G.; Zong, J.C.; Hokello, J.; Sussman, N.; Simms, S.; Rockwell, R.F.; Pozos, R.; Hayward, G.S.; Boto, W. Ugandan Kaposi's Sarcoma-Associated Herpesvirus Phylogeny: Evidence for Cross-Ethnic Transmission of Viral Subtypes. Intervirology 2006, 49, 133-143. [CrossRef] [PubMed]

108. Mbulaiteye, S.; Marshall, V.; Bagni, R.K.; Wang, C.-D.; Mbisa, G.; Bakaki, P.M.; Owor, A.M.; Ndugwa, C.M.; Engels, E.A.; Katongole-Mbidde, E.; et al. Molecular Evidence for Mother-to-Child Transmission of Kaposi Sarcoma-Associated Herpesvirus in Uganda and K1 Gene Evolution within the Host. J. Infect. Dis. 2006, 193, 1250-1257. [CrossRef] [PubMed]

109. Duprez, R.; Hbid, O.; Afonso, P.; Quach, H.; Belloul, L.; Fajali, N.; Ismaili, N.; Benomar, H.; Hassane Tahri, E.; Huerre, M.; et al. Molecular Epidemiology of the HHV-8 K1 Gene from Moroccan Patients with Kaposi's Sarcoma. Virology 2006, 353, 121-132. [CrossRef] [PubMed]

110. Malope, B.I.; Pfeiffer, R.M.; Mbisa, G.; Stein; Ratshikhopha, E.M.; O'Connell, D.L.; Sitas, F.; MacPhail, P.; Whitby, D. Transmission of Kaposi sarcoma-associated herpesvirus between mothers and children in a South African population. J. Acquir. Immune Defic. Syndr. 2007, 44, 351-355. [CrossRef] [PubMed]

111. Rohner, E.; Natascha, W.; Sven, T.; Sam, M.M.; Patthias, E.; Urban, N.; Marcel, Z.; Julia, B. HHV-8 seroprevalence: A global view. Syst. Rev. 2016, 3, 11. [CrossRef] [PubMed]

(C) 2018 by the authors. Licensee MDPI, Basel, Switzerland. This article is an open access article distributed under the terms and conditions of the Creative Commons Attribution (CC BY) license (http://creativecommons.org/licenses/by/4.0/). 